Grossman, J. P. \& Postgate, J. R. (1955). J. gen. Microbiol. 12, 429-445

\title{
The Metabolism of Malate and certain other Compounds by Desulphovibrio desulphuricans
}

\author{
By JOY P. GROSSMAN and J. R. POSTGATE \\ Chemical Research Laboratory, Teddington, Middlesex
}

SUMMARY: Desulphovibrio desulphuricans (strain El Agheila Z) oxidized malate, fumarate, succinate, lactate and pyruvate quantitatively to acetate in cultures containing excess sulphate. Polysaccharide accumulated in old cultures.

Cell suspensions harvested from malate media yielded theoretical amounts of sulphide and $\mathrm{CO}_{2}$ from malate, fumarate or succinate + excess sulphate. Succinate was formed transiently during malate oxidation. Various inorganic sulphur-containing anions, methylene blue or oxygen acted as alternative hydrogen acceptors to sulphate for malate oxidation. In the absence of sulphate, malate was metabolized yielding acetate, $\mathrm{CO}_{2}$ and succinate in the molar ratio 3 malate $\rightarrow 2$ succinate $+2 \mathrm{CO}_{2}+$ acetate; in hydrogen, malate or fumarate were partly reduced to succinate. Malate or fumarate accelerated the reduction of sulphate, but not dithionite, in hydrogen. Suspensions treated with cetyltrimethylammonium bromide formed fumarate and lactate $+\mathrm{CO}_{2}$ from malate. Fumarate was formed via a reversible fumarase; lactate was formed via a decarboxylase system independent of cozymase, $\mathrm{Mn}^{++}$, cocarboxylase or codecarboxylase.

Cell suspensions harvested from lactate media yielded theoretical amounts of sulphide and $\mathrm{CO}_{2}$ from lactate or pyruvate + excess sulphate. In the presence of arsenite, pyruvate was formed from lactate; pyruvate formation was demonstrated with another strain.

Suspensions of strain California 43:63 harvested from lactate media reduced fumarate in $\mathbf{H}_{2}$ quantitatively to succinate ; crotonate, maleate or acetylene-dicarboxylate were not reduced; malate was reduced slowly.

Hence the reaction sequence : succinate $\rightleftharpoons$ fumarate $\rightleftharpoons$ malate $\rightarrow$ lactate $\rightarrow$ pyruvate $\rightarrow$ acetate probably takes place in these bacteria; a reversible succinate $\rightleftharpoons$ fumarate system may form a link between sulphate reduction and the oxidation of organic compounds or hydrogen.

Malate was the carbon source originally used by Beijerinck (1895) for the cultivation of sulphate-reducing bacteria, though lactate, introduced by his pupil van Delden (1903), has since been more widely used. There have been relatively few detailed studies of the metabolism of carbon compounds by sulphate-reducing bacteria. Baars (1930) examined the ability of many organic compounds to support growth of the bacteria and showed that acetate was usually an end product of carbon compound oxidation. Senez (1951) showed that pyruvate oxidation was accompanied by greater growth and less sulphide formation than was lactate oxidation, and Postgate (1952a) showed that growth in the absence of sulphate could occur in pyruvate media, the 'sulphate-free' metabolism giving $\mathrm{CO}_{2}$, acetate and ethanol among its products (Postgate, 1952b). Subsequently, Sadana (1954) obtained an extract which converted pyruvate to ethanol and acetyl phosphate from acetonedried cells of the Hildenborough strain. Millet (1954) obtained an extract from dried cells of a different strain which converted pyruvate to acetyl 
phosphate, $\mathrm{CO}_{2}$ and $\mathrm{H}_{2}$. Senez \& Leroux-Gilleron (1954) also recorded formation of hydrogen during pyruvate or cysteine metabolism without sulphate. Senez (1954a) showed that the relative rates of oxidation of carbon sources including lactate, pyruvate, malate, fumarate and succinate depended on the media from which the cells had been harvested, and that strain Canet 41 did not attack the dicarboxylic acids without previous 'adaptation' to fumarate. The present paper describes mainly the metabolism of malate by a halophilic strain of Desulphovibrio desulphuricans, though stages relevant to the metabolism of lactate, succinate, fumarate and pyruvate have been demonstrated during the work. Part of this work has been reported elsewhere (Chemistry Research 1952, 1953).

\section{METHODS}

Organisms. Desulphovibrio desulphuricans strain El Agheila Z (National Collection of Industrial Bacteria, NCIB 8380) was originally a hydrogenasefree halophilic strain isolated from a sulphur-bearing lake in Libya (Adams, Butlin, Hollands \& Postgate, 1951). A hydrogenase-containing variant of that strain was used in this work. Strain New Jersey SW 8 (NCIB 8315) was a marine halophilic strain kindly provided by Professor R. L. Starkey. These strains were maintained on a malate medium. Strain California 43:63 (NCIB 8364) was a marine halophilic organism kindly provided by Professor C. E. ZoBell; it was maintained on a lactate medium. Strain Hildenborough (NCIB 8304) was a non-halophilic strain used in other work from this laboratory. All were typical motile obligately anaerobic vibrios; the cultures were checked for purity at intervals using the procedure described by Postgate (1953).

Cultivation. Stocks were kept in a freeze-dried condition, but during work on a particular strain it was maintained by weekly subculture at $30^{\circ}$ in either $(a)$ the lactate medium $\mathrm{C}$ of Butlin, Adams \& Thomas (1949) supplemented with $\mathrm{NaCl} 2.5 \%(\mathrm{w} / \mathrm{v})$, or $(b)$ a similar medium containing sodium hydrogen malate $0.5 \%(\mathrm{w} / \mathrm{v})$ in place of sodium lactate. Cultures were grown in $6 \times \frac{5}{8}$ in. test tubes with a plug containing $1: 1(\mathrm{v} / \mathrm{v})$ pyrogallol (sat.) and $\mathrm{Na}_{2} \mathrm{CO}_{3}$ (sat.). For manometric or fermentation experiments, organisms were harvested by centrifugation from 3- to 5 -day-old cultures in flasks $(100 \mathrm{ml}$. to 2 1.) using similar media but containing yeast extract ('Difco') $0 \cdot 4 \%$ (w/v) and sodium sulphide $c .5 \times 10^{-3} \mathrm{M}$ (see Grossman \& Postgate, 1953) to accelerate growth. Such organisms were washed once in either $\mathrm{NaCl} 2.5 \%(\mathrm{w} / \mathrm{v})$ or saline phosphate buffer (below).

Standardization of suspensions. To avoid errors due to osmotic leakage, cell suspensions were standardized turbidimetrically and related to a calibration curve of a non-halophilic strain (Hildenborough). Dry weights recorded in this paper are thus the dry weights of a suspension of organisms of the Hildenborough strain of equivalent turbidity.

Detection and estimation of organic acids. These were detected by ascending chromatography on Whatman no. 1 filter paper sheets using $n$-butanol/3 $\mathrm{N}-\mathrm{NH}_{4} \mathrm{OH}(1: 1)$ for steam-volatile acids and $n$-butanol/acetic acid/ $\mathrm{H}_{2} \mathrm{O}(4: 1: 5)$, 
di-isopropyl ketone/formic acid/ $\mathrm{H}_{2} \mathrm{O}(4: 1: 5)$ or amyl alcohol/formic acid/ $\mathrm{H}_{2} \mathrm{O}$ $(5: 2: 5)$ for non-volatile acids. The dried papers were sprayed with bromthymol blue or bromcresol green respectively. All chromatograms were run with markers and without special temperature control. The identity of acetic acid in bacterial products was confirmed by Duclaux distillation; it was estimated by titration in $\mathrm{CO}_{2}$-free air after steam distillation followed by re-distillation with $\mathrm{MgSO}_{4}+\mathrm{HgO}$ (Friedemann, 1938).

Succinic acid was detected by the resorcinol test and by chromatography. It was estimated in bacterial products by extraction into ether, transfer to water and titration after steam distillation to remove acetic acid. The titration residues were concentrated and chromatographed to confirm the absence of contaminating acids.

Pyruvic acid was estimated by the method of Friedemann \& Haugen (1943) and identified by descending chromatography of the 2:4-dinitrophenylhydrazone in $n$-butanol $/ 2 \mathrm{~N}-\mathrm{NH}_{4} \mathrm{OH}(1: 1)$. Lactic acid was estimated by Neish's (1950) modification of Barker \& Summerson's (1941) method.

Other estimations. Total carbohydrate was determined by the anthrone reaction (Neish, 1950). Carbon compounds volatile in steam at $\mathrm{pH} \mathbf{7 \cdot 0}$ were estimated by the procedure given by Neish (1950) for ethanol.

Manometry. The conventional Warburg manometer was used for gas exchange measurements. Cadmium chloride $(0.25 \mathrm{ml}$. of $10 \%, \mathrm{w} / \mathrm{v})$ on glass wool was normally used in the centre well or in a detachable container to absorb $\mathrm{H}_{2} \mathrm{~S}$ displaced by the buffer, and the main compartment, after tipping, contained $2.75 \mathrm{ml}$. of reaction fluid including substrates, and 5-10 mg. dry wt. cells in saline buffer. Saline buffer contained $\mathrm{NaCl}(2.5 \%, \mathrm{w} / \mathrm{v})+\mathrm{KH}_{2} \mathrm{PO}_{4}$ $(0.5 \%, \mathrm{w} / \mathrm{v})$ and the $\mathrm{pH}$ was adjusted with $2 \mathrm{~N}-\mathrm{NaOH}$. This buffer was supplemented with $\mathrm{Na}_{2} \mathrm{HPO}_{4}(0 \cdot 4 \%$, w/v) for studies with dicarboxylic acids to improve its buffering capacity. Manometers were incubated at $37^{\circ}$; their constants were corrected for $\mathrm{CO}_{2}$ retention by the buffer at $\mathrm{pH}$ values $>\mathbf{5 \cdot 0}$. Vessels were flushed out with $\mathbf{H}_{2}$ (British Oxygen Co.) or 'oxygen-free' $\mathrm{N}_{2}$ (British Oxygen Co.) containing less than 10 v.p.m. $\mathrm{O}_{2}$. $Q$ values represent $\mathrm{mm} .{ }^{3}$ gas exchanged/mg. dry wt. cells/hr.; the most commonly obtained values for a given substrate are quoted, with the highest and lowest values encountered as the range.

Estimation of sulphide. (a) Cultures. The culture was incubated under $\mathrm{N}_{2}$ in a sealed vessel filled as full as possible so that errors due to $\mathrm{H}_{2} \mathrm{~S}$ in the gas phase should be minimal. After growth, $2 \mathrm{ml}$. samples of culture were pipetted immediately into excess $\mathrm{I}_{2}$ which was back-titrated against standard $\mathrm{Na}_{2} \mathrm{~S}_{2} \mathrm{O}_{3}$ with starch as indicator. Experiments in this laboratory with cells grown in sulphate-free conditions indicated that $1 \mathrm{mg}$. dry wt. cells absorbed $I_{2}$ equivalent to $2 \cdot 2 \mu$ mole sulphide; this correction was applied to all cultures analysed directly for sulphide. (b) Manometric experiments. The $\mathrm{CdCl}_{2}$ plug was transferred to acid $0.01 \mathrm{~N}-\mathrm{I}_{2}$ in stoppered tapered tubes and the residual $\mathrm{I}_{2}$ titrated against $0.001 \mathrm{~N}-\mathrm{Na}_{2} \mathrm{~S}_{2} \mathrm{O}_{3}$ with $\mathrm{CCl}_{4}$ as internal indicator (see Postgate, 1951).

Methylene-blue reduction times were measured by incubating washed and buffered cell suspensions $(c .0 .3 \mathrm{mg} . / \mathrm{ml}$.) in conventional Thunberg tubes 
in vacuo at $30^{\circ}$ with $0 \cdot 1 \mu$ mole methylene blue (British Drug Houses Ltd., 'biological' grade) and $c .7 \cdot 5 \mu$ mole substrate.

Reagents. Analytical grade reagents were used wherever possible. Sodium hydrogen malate (British Drug Houses Ltd.) was used in the malate medium, but L-malic acid (L. Light and Co.) was used in metabolic experiments. Sodium pyruvate and sodium fumarate were prepared in the laboratory from pyruvic and fumaric acids (L. Light and Co.). Cetyltrimethylammonium bromide (CTAB) recrystallized from acetone was kindly provided by $\mathrm{Dr}$ V. A. Knivett.

\section{RESULTS}

\section{Preliminary observations}

Growth of strain El Agheila $\mathrm{Z}$ in the malate medium was detectable after $\mathbf{2 4} \mathrm{hr}$., and reached its maximum cell density in 4 days. Growth was similar to that with lactate or fumarate, less than that with pyruvate (see Senez, 1951) but greater than that with succinate (Table 1). After very prolonged incubation the cell density apparently declined owing to coagulation of the bacteria,

Table 1. Growth and acetate formation in cultures of Desulphovibrio desulphuricans ( $E l$ Agheila $\mathbf{Z}$ ) with various carbon sources

Cultures $\left(10 \mathrm{ml}\right.$.) were inoculated with $0.1 \mathrm{ml}$. of parent culture and incubated at $30^{\circ}$ in $\mathbf{N}_{2}$ until maximum cell densities or acetate yields were reached.

(A) Growth. Media contained $31 \mu$ mole sodium salt of C-source $/ \mathrm{ml}$., $15 \cdot 5 \mu \mathrm{mole} \mathrm{SO}_{4}^{\prime \prime} / \mathrm{ml}$., $0.1 \%$ yeast extract, $\mathrm{Na}_{2} \mathrm{~S}(5 \mu \mathrm{mole} / \mathrm{ml}$.) and various salts (see text). Means of quintuplicate readings quoted.

$\begin{array}{clc}\begin{array}{c}\text { Substrate } \\ \text { of inoculum }\end{array} & \begin{array}{c}\text { Substrate } \\ \text { of test } \\ \text { cultures } \\ \text { Malate }\end{array} & \begin{array}{c}\text { Final } \\ \text { cell density } \\ (\mu \mathrm{g} . \text { dry wt. } \\ \text { cells } / \mathrm{ml} .)\end{array} \\ \text { Malate } & \text { L-Malate } & \mathbf{3 4 0} \\ \text { Malate } & \text { Fumarate } & \mathbf{3 4 0} \\ \text { Malate } & \text { Succinate } & \mathbf{3 4 0} \\ \text { Lactate } & \text { DL-Lactate } & \mathbf{1 2 0} \\ \text { Lactate } & \text { Pyruvate } & \mathbf{3 2 0} \\ \text { Either } & - & \mathbf{5 9 0} \\ & & \mathbf{2 5}\end{array}$

(B) Acetate yield. Media as above except C-sources reduced to $15 \cdot 5 \mu$ mole-ml. to leave sulphate in excess. Inoculum substrates as above. Means of triplicate readings quoted.

\begin{tabular}{|c|c|c|}
\hline Test substrate & $\begin{array}{c}\text { Final } \\
\text { acetate } \\
\text { conc. } \\
(\mu \mathrm{mole} / \mathrm{ml} .)\end{array}$ & $\begin{array}{l}\text { Incubation } \\
\text { required to } \\
\text { reach maximum } \\
\text { acetate yield } \\
\text { (days) }\end{array}$ \\
\hline DL-Malate & 18 & 4 \\
\hline Fumarate & $17 \cdot 5$ & 4 \\
\hline Succinate & 18 & 8 \\
\hline DL-Lactate & $18 \cdot 5$ & 4 \\
\hline Pyruvate & $18 \cdot 2$ & 2 \\
\hline - & 2.5 & 2 \\
\hline
\end{tabular}

Note: 'blank' growth and acetate formation are due to oxidizable carbon in the yeast extract. 
and polysaccharide could be demonstrated in the supernatant medium by the anthrone reaction and the increased viscosity; a 22-day culture gave an anthrone reaction equivalent to $1.0 \mu$ mole glucose $/ \mathrm{ml}$. Similar phenomena were observed in cultures grown with fumarate, succinate or lactate. Senez (1953) mentioned polysaccharide formation in 'semi-autotrophic' cultures of strain Canet 41. Polysaccharide formation by El Agheila Z was not investigated further.

Washed cell suspensions of strain $\mathbf{E l}$ Agheila $\mathrm{Z}$ reduced methylene-blue anaerobically in the presence of malate whether harvested from malate or lactate media, in contrast to New Jersey SW 8 (below). Both L-malate and DL-malate were metabolized by cell suspensions in the presence of sulphate, yielding $\mathrm{CO}_{2}$ at similar initial rates and in similar amounts. Malate was oxidized in the presence of sulphite, thiosulphate, tetrathionate or dithionite (cf. Postgate, 1951); it was also slowly oxidized with oxygen (as a $96 \% \mathbf{N}_{2}$ $+4 \% \mathrm{O}_{2}, \mathrm{v} / \mathrm{v}$, mixture) as a hydrogen acceptor $\left(-Q_{\mathrm{O}_{2}} c .10\right)$; Postgate $(1954 b)$ showed reactions of this kind with the Hildenborough strain and demonstrated that the hydrogen/oxygen reaction was cytochrome-linked.

Five other strains of Desulphovibrio desulphuricans tested by the methyleneblue procedure showed the presence of a malic dehydrogenase system, even when they had never been grown in a malate medium. A sixth strain, New Jersey SW 8, did not show this (Table 5), but after subculture in malate medium it developed the ability to reduce methylene blue with malate; thus its behaviour resembled that of Senez's Canet 41.

\section{Malate oxidation during sulphate reduction}

Washed suspensions of EI Agheila $\mathrm{Z}$ harvested from malate medium oxidized L-malate in the presence of excess sulphate to yield $2 \mu$ mole $\mathrm{CO}_{2} / \mu$ mole malate oxidized (Fig. 1); $0.5 \mu$ mole $S^{\prime \prime}$ was formed (Table 3). No gas change was observed when there was $\mathrm{NaOH}$ in the centre well, hence no gas other than $\mathrm{CO}_{2}$ was formed. Analyses of cultures grown in the malate medium compared with control cultures from which malate was omitted indicated a maximum yield of one $\mu$ mole acetate/ $\mu$ mole malate (Table 1 ). Thus the total yields of $\mathrm{CO}_{2}$, sulphide and acetate were consistent with the formal equation:

$$
\underset{2 \mathrm{CHOH} . \mathrm{COOH}}{\mathrm{CH}_{2} \cdot \mathrm{COOH}}+\mathrm{Na}_{2} \mathrm{SO}_{4}=2 \mathrm{CH}_{3} \cdot \mathrm{COOH}+4 \mathrm{CO}_{2}+\mathrm{Na}_{2} \mathrm{~S}+4 \mathrm{H}_{2} \mathrm{O} .
$$

However, two types of experiment showed that the reaction was more complex than indicated in this equation. First, the equation requires that the acetate:sulphide ratio in cultures at all stages of growth should be $2: 1$, but analyses of cultures before all the malate had been converted to acetate gave ratios nearer to 3:1. Typical figures were: $(a)$ a 3-day culture contained $7 \cdot 0 \mu \mathrm{mole} / \mathrm{ml}$. acetate and $2 \cdot 43 \mu \mathrm{mole} / \mathrm{ml}$. sulphide (ratio $=3: 1 \cdot 04) ;(b) 10$-day culture contained $15 \cdot 25 \mu \mathrm{mole} / \mathrm{ml}$. acetate and $5.02 \mu \mathrm{mole} / \mathrm{ml}$. sulphide (ratio $=$ $3: 0 \cdot 99)$. Succinate, lactate and fumarate were sometimes detected chromato- 
graphically in ether extracts of such cultures. Secondly, $\mathrm{CO}_{2}$-evolution curves showed that malate oxidation by cell suspensions at $\mathrm{pH} 6 \cdot 1$ took place at two distinct rates (Fig. 1). These double-rate curves were responsible for the difficulties reported in establishing $\mathrm{CO}_{2}$ : malate ratios in earlier stages of this work (Chemistry Research 1952, 1953). Malate was oxidized with an initial $\mathrm{Q}_{\mathrm{Co}_{2}}$ of $c .40$ (variance: 30 to 60 ) and after $c .1 \cdot 3 \mu$ mole $\mathrm{CO}_{2} / \mu$ mole malate had been evolved the reaction rate slowed down to a $Q_{\mathrm{Co}_{2}}$ of $c .10$ (range: 5 to 15). Cells with sulphate but without malate had a $\mathrm{Q}_{\mathrm{Co}_{2}}$ of $c .2 \cdot 5$ (range: 2 to 3). The lower quotient with malate corresponded to that of a similar cell suspension oxidizing succinate; lactate or pyruvate was usually oxidized faster than succinate but slower than malate, though cell suspensions sometimes did not oxidize lactate or pyruvate at all. The form of the curves suggested accumulation of an intermediate which was then metabolized at a slower rate than malate. The rate suggested that it might be succinate, which was isolated and characterized (see Methods) by interrupting the metabolism of malate at various stages, ether-extracting the acidified supernatant and chromatographing the extract. Succinate appeared soon after the start of malate oxidation but had disappeared by the time $\mathrm{CO}_{2}$ evolution had fallen to the 'blank' rate.

\section{Malate dismutation without sulphate}

Malate was metabolized more slowly by strain El Agheila $\mathbf{Z}$ in the absence of sulphate; $Q_{\mathrm{CO}_{2}}$ c. 20 (range: 15 to 25). No gas other than $\mathrm{CO}_{2}$ was formed. When methylene blue was added after $\mathrm{CO}_{2}$ evolution had ceased, it was decolorized, indicating accumulation of a substance capable of acting as a

Table 2. Malate metabolism of Desulphovibrio desulphuricans (El Agheila Z) without sulphate

Acetate and succinate were estimated after fermentation of $30 \mu \mathrm{mole} / \mathrm{ml}$. of malate in $\mathrm{N}_{2}$ at $37^{\circ}$ by cell suspensions (4-10 mg. dry wt. $/ \mathrm{ml}$.) until manometric controls indicated that all $\mathrm{CO}_{2}$ evolution had ceased (5-27 hr., depending on suspension density used).

$\begin{array}{ccccc}\begin{array}{c}\text { Succinate } \\ (\mu \mathrm{mole} / \mathrm{ml} .)\end{array} & \begin{array}{c}\text { Acetate } \\ (\mu \mathrm{mole} / \mathrm{ml} .)\end{array} & \begin{array}{c}\text { Succinate } \\ (\mu \mathrm{mole} / \mathrm{ml} .)\end{array} & \begin{array}{c}\text { Acetate } \\ (\mu \mathrm{mole} / \mathrm{ml} .)\end{array} \\ & 23.2 & 9.0 & - & - \\ 19.9 & 10.4 & 0.7 & 1.4 \\ & 20.6 & 11.9 & 2.1 & 1.8 \\ \text { Mean } & \mathbf{1 9 . 4} & 11.7 & - & - \\ \sigma & 1.46 & 10.75 & 1.4 & 1.6 \\ & 1.46 & 1.16 & - & -\end{array}$

hydrogen donor in the bacterial metabolism. A similar effect was reported in the dismutation of pyruvate without sulphate (Postgate, 1952b). This hydrogen donor was not free hydrogen since only $\mathrm{CO}_{2}$ was present in the gas phase and, when sulphate was added after malate dismutation had ceased, $\mathrm{CO}_{2}$ was evolved and sulphide formed.

Examination of the end products of malate dismutation without sulphate 
showed the presence of succinate. Manometric experiments showed that 0.62 to $0.81 \mu$ mole $\mathrm{CO}_{2}$ was evolved/ $\mu$ mole malate metabolized (mean of six experiments $=0.716 \mu$ mole $\mathrm{CO}_{2}, \sigma=0.0575$ ); rather high 'blank' values for $\mathrm{CO}_{2}$ evolution were encountered in these experiments. Fermentation experiments in which cell suspensions were shaken with relatively large quantities of substrate until manometric controls indicated that gas evolution had ceased yielded approximately $2 \mu$ mole succinate and $1 \mu$ mole acetate from $\mathbf{3} \mu$ mole malate (Table 2). No increase in the total polysaccharide content of cells could be demonstrated, but traces were detected of a compound which was volatile in steam at neutral $\mathrm{pH}$ and which was oxidized by acid dichromate. It was not identified unequivocally as ethanol, but, calculated as ethanol, it accounted for less than $3 \%$ of the malate utilized.

\section{Formation of fumarate}

Succinate, $\mathrm{CO}_{2}$ and acetate were thus the main products of malate dismutation. Attempts were made to demonstrate fumarate formation during the formation of succinate from malate. Acetone-dried cells, cell extracts obtained by grinding with $\mathrm{Al}_{2} \mathrm{O}_{3}$, or cells metabolizing malate in air did not accumulate fumarate, but cells treated with cetyltrimethylammonium bromide (CTAB) did so. In a typical experiment, a cell suspension in distilled water of $50 \mu \mathrm{g}$ dry wt. cells/vessel (1 ml.), treated with CTAB (50 $\mu \mathrm{g} . / \mathrm{mg}$. dry wt. cells) and incubated with $125 \mu$ mole malate or fumarate in $\mathrm{N}_{2}$, formed a mixture of malate and fumarate from either substrate, the products being identified chromatographically.

\section{Succinate oxidation}

Since succinate was clearly involved in malate metabolism, its oxidation by El Agheila $Z$ grown in malate was examined. Succinate was not metabolized in the absence of sulphate, but in its presence cell suspensions slowly yielded $2 \mu$ mole $\mathrm{CO}_{2} / \mu$ mole succinate $\left(Q_{\mathrm{Co}_{2}}\right.$ c. 10$)$ and $0.75 \mu$ mole sulphide (Table 3 ). Analyses of cultures (Table 1 ) showed that $1 \mu$ mole acetate was formed $/ \mu$ mole succinate utilized. These observations are consistent with the equation:

$$
\underset{4 \mathrm{CH}_{2} \cdot \mathrm{COOH}}{\mathrm{CH}_{2} \cdot \mathrm{COOH}}+3 \mathrm{Na}_{2} \mathrm{SO}_{4}=4 \mathrm{CH}_{3} \cdot \mathrm{COOH}+8 \mathrm{CO}_{2}+3 \mathrm{Na}_{2} \mathrm{~S}+4 \mathrm{H}_{2} \mathrm{O} \text {. }
$$

Fumarate metabolism

With sulphate. Fumarate was metabolized in a manner similar to malate: a rapid initial $Q_{\mathrm{Co}_{2}}$ of $c .40$ was observed and, after $c .1 \cdot 3 \mu \mathrm{mole} \mathrm{CO}_{2} / \mu$ mole fumarate had been evolved, a lower $Q_{\mathrm{CO}_{2}}$ value of $c$. 10. Sulphide was formed to the extent of $0.5 \mu$ mole $S^{\prime \prime} / \mu$ mole fumarate oxidized (Table 3). Analyses of cultures grown with excess of sulphate yielded $1 \mu$ mole acetic acid $/ \mu$ mole fumarate (Table 1). These observations agree with the equation

$$
\underset{2 \|}{\mathrm{CH} . \mathrm{COOH}}+\mathrm{Na}_{2} \mathrm{SO}_{4}=2 \mathrm{CH}_{3} \cdot \mathrm{COOH}+4 \mathrm{CO}_{2}+\mathrm{Na}_{2} \mathrm{~S} \text {. }
$$


Without sulphate. Cell suspensions without sulphate metabolized fumarate and malate at similar rates-consistent with the presence of fumarase in the cells-though $\mathrm{CO}_{2}$ yields with fumarate were consistently slightly higher than with malate. Three separate determinations gave $0.78,0.71$ and $0.89 \mu$ mole $\mathrm{CO}_{2} / \mu$ mole fumarate (cf. Table 2 ); succinate and acetate were detected as end products of the reaction.

Table 3. Sulphide yields from Desulphovibrio desulphuricans strain El Agheila $Z$ with sulphate and various carbon sources

Cell suspensions were shaken in Warburg manometers $\left(\mathrm{N}_{2}, 37^{\circ}\right)$ and the sulphide formed was determined after $\mathrm{CO}_{2}$ evolution had reached the 'blank' level. Figures are corrected for blank sulphide yields $\left(<0.5 \mu\right.$ mole $\left.S^{\prime \prime}\right)$.

\begin{tabular}{|c|c|c|c|c|}
\hline $\begin{array}{c}\text { Substrate } \\
\text { ( } \mu \text { mole })\end{array}$ & $\begin{array}{l}\mathrm{Na}_{2} \mathrm{SO}_{4} \\
(\mu \mathrm{mole})\end{array}$ & $\begin{array}{c}\text { Cell density } \\
(\mu \mathrm{g} . \text { dry wt./ml. })\end{array}$ & $\begin{array}{c}\text { Sulphide } \\
\text { formed } \\
\text { ( } \mu \text { mole) }\end{array}$ & $\begin{array}{c}\text { Theoretical } \\
\text { sulphide } \\
\text { ( } \mu \text { mole) }\end{array}$ \\
\hline Lactate* 5 & $\mathbf{5}$ & $1 \cdot 75$ & $2 \cdot 46$ & $2 \cdot 5$ \\
\hline Pyruvate* 5 & 5 & $\mathbf{3 \cdot 2}$ & $1 \cdot 25$ & $1 \cdot 25$ \\
\hline L-Malate 5 & 20 & 4.5 & $2 \cdot 65$ & $2 \cdot 5$ \\
\hline Fumarate 5 & 20 & $7 \cdot 6$ & $2 \cdot 45$ & $2 \cdot 5$ \\
\hline Succinate 5 & 20 & 10 & $\mathbf{3 \cdot 6 9}$ & 3.75 \\
\hline
\end{tabular}

Fumarate reduction. Sisler \& ZoBell (1951) reported certain autotrophic marine strains of Desulphovibrio desulphuricans which were able to reduce fumarate with hydrogen in place of sulphate; sometimes their strains reduced fumarate faster than sulphate. Since fumarate might be acting as a hydrogen acceptor in the formation of succinate from malate by $\mathrm{El}$ Agheila $\mathrm{Z}$, fumarate reduction was investigated further. Strain California $43: 63$, grown on lactate medium ( $-Q_{\mathrm{H}_{2}}$ with sulphate $\left.c .20\right)$ reduced fumarate in hydrogen with a $-Q_{\mathrm{H}_{2}}$ of c. 37 (range: 47 to 20 ) and absorbed $1 \mu$ mole $\mathrm{H}_{2} / \mu$ mole fumarate (Fig. 2). Succinate was identified in the reaction products. This suggested a reaction which may be represented:

$$
\underset{\mathrm{CH} \cdot \mathrm{COOH}}{\mathrm{CH}}+\mathrm{COOH}+\mathrm{H}_{2}=\underset{\mathrm{CH}_{2} \cdot \mathrm{COOH}}{\mathrm{CH}_{2} \cdot \mathrm{COOH}}
$$

Malate was reduced very slowly $\left(-Q_{\mathrm{H}_{2}}\right.$ c. 16 , compared with 'blank' $-Q_{\mathrm{H}_{2}}$ of c. 13), but otherwise the reaction was highly specific; maleate, crotonate or acetylene dicarboxylate were not reduced, though these acids are structurally similar to fumarate. Fumarate did not replace sulphate for growth of the organism in the autotrophic medium of Butlin \& Adams (1947). Three other laboratory strains (Hildenborough, New Jersey SW 8, Canet 41) did not reduce fumarate in hydrogen.

Strain El Agheila $\mathrm{Z}$ was able to reduce fumarate slowly whether harvested from lactate or malate media. In the latter case $c$. $1 \mu$ mole $\mathrm{H}_{2}$ was absorbed/ $\mu$ mole fumarate reduced $\left(-Q_{\mathrm{H}_{2}}\right.$ c. 10$)$, but some $\mathrm{CO}_{2}$ evolution occurred during the reaction, indicating that the dismutation reaction was proceeding simultaneously. Malate was reduced in place of fumarate, but more slowly $\left(-Q_{\mathrm{H}_{2}}\right.$ c. 5$)$. 


\section{Formation of lactate}

The compounds so far demonstrated in malate metabolism were $\mathrm{CO}_{2}$, acetate, fumarate and succinate. Theoretical considerations (see Discussion) required that the dehydration and reduction of malate to succinate should be accompanied by a parallel oxidation of malate to acetate, and intermediates in this step were therefore sought. CTAB-treated cells such as those used to demonstrate fumarase activity (above), showed very slow $\mathrm{CO}_{2}$ evolution from

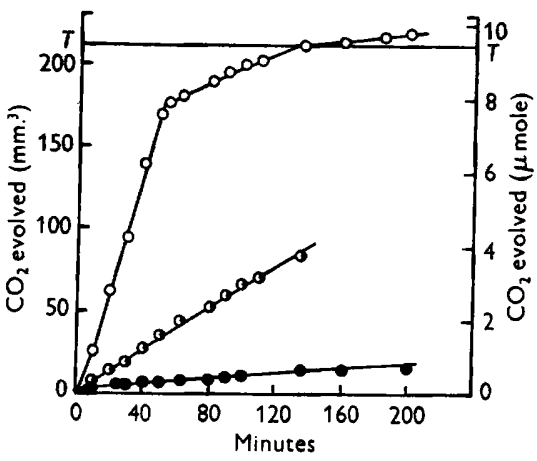

Fig. 1

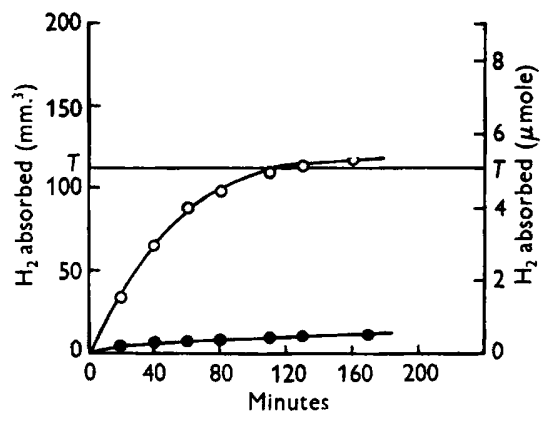

Fig. 2

Fig. 1. $\mathrm{CO}_{2}$-evolution curves from Desulphovibrio desulphuricans strain El Agheila $\mathrm{Z}$ when oxidizing malate or succinate with sulphate. Manometer vessels contained 3.7 mg. dry wt. washed cells (harvested from malate medium) in $\mathrm{N}_{2}$ at $37^{\circ}, \mathrm{pH} 6 \cdot 1, \mathrm{CdCl}_{2}$ in centre well. $\mathrm{O}-\mathrm{O}-\mathrm{O}$, L-malate $(4.75 \mu \mathrm{mole}) . \quad T$ indicates theoretical volume of $\mathrm{CO}_{2}$ for molar ratio 1 malate $\rightarrow 2 \mathrm{CO}_{2}$. $-\mathrm{O}-\mathrm{O}$, succinate $(5 \mu \mathrm{mole})$. $-0-0$, no substrate.

Fig. 2. Reduction of fumarate in hydrogen by Desulphovibrio desulphuricans strain California 43:63. Manometer vessels contained $3 \cdot 1 \mathrm{mg}$. dry wt. washed cells (harvested from lactate medium) in $\mathrm{H}_{2}$ at $37^{\circ}, \mathrm{pH} \mathrm{6.3}, \mathrm{NaOH}$ in centre well. $-Q_{\mathrm{H}_{2}}$ (fumarate) c. 28; $T$ indicates theoretical volume of $\mathrm{H}_{2}$ for fumarate $+\mathrm{H}_{2} \rightarrow$ succinate. $\mathrm{O}-\mathrm{O}-\mathrm{O}$ fumarate (5 $\mu$ mole),

malate in the presence of sulphate $\left(\boldsymbol{Q}_{\mathrm{co}_{2}}\right.$ c. 2.6) which was nevertheless in excess of the blank $\left(Q_{\mathrm{CO}_{2}}\right.$ c. $\left.0 \cdot 9\right)$. The supernatants of such preparations analysed after various time intervals contained significant amounts of lactate; pyruvate was present in traces. Comparisons of the amounts of $\mathrm{CO}_{2}$ evolved and lactate formed are given in Table 4; there is reasonable agreement with a simple decarboxylation of malate to lactate. Nossal (1951) observed that the malic decarboxylase system of acetone-dried Lactobacillus arabinosus required $\mathrm{Mn}^{++}$and cozymase for maximum activity. Neither the rate of $\mathrm{CO}_{2}$ evolution nor the amount of lactate formed by CTAB-treated El Agheila Z was affected by $\mathrm{MnSO}_{4}\left(2 \times 10^{-3} \mathrm{M}\right)$, cozymase $(0.8 \mathrm{mg} . / \mathrm{ml}$.), both together, cocarboxylase $(0.4 \mathrm{mg} . / \mathrm{ml}$.) or pyridoxal phosphate $(0.2 \mathrm{mg} . / \mathrm{ml}$.). 


\section{Lactate metabolism}

The lactate metabolism of El Agheila $\mathbf{Z}$ was therefore examined using cells habitually grown in lactate media. Analyses of cultures grown with lactate and excess of sulphate gave final yields of $1 \mu$ mole acetate $/ \mu$ mole lactate utilized (Table 1). Neither growth of bacteria nor $\mathrm{CO}_{2}$ evolution from suspen-

Table 4. Formation of lactate from malate by $C T A B$-treated Desulphovibrio desulphuricans strain El Agheila $\mathbf{Z}$

Cells were harvested from the malate medium, washed in saline phosphate buffer (pH 6·1) and shaken in $\mathrm{N}_{2}$ at $37^{\circ}$ with $5 \mu$ mole malate and $50 \mu \mathrm{g}$ CTAB $/ \mathrm{mg}$. dry wt. cells in Warburg manometers. Lactate was determined in the supernatant after incubation. Three experiments recorded.

\begin{tabular}{|c|c|c|c|c|c|}
\hline $\begin{array}{l}\text { Malate } \\
\text { ( } \mu \text { mole/ } \\
\text { vessel) }\end{array}$ & $\begin{array}{c}\text { Cells } \\
\text { (mg./vessel) }\end{array}$ & $\begin{array}{c}\text { Incubation } \\
\text { time } \\
\text { (min.) }\end{array}$ & $\begin{array}{c}\mathrm{CO}_{2} \\
\text { evolved } \\
(\mu \mathrm{mole})\end{array}$ & $\begin{array}{c}\text { Lactate } \\
\text { ( } \mu \text { mole/ } \\
\text { vessel) }\end{array}$ & $\begin{array}{c}\mathrm{CO}_{2} \text { : Lactate } \\
\text { (corrected } \\
\text { for blank) }\end{array}$ \\
\hline 5 & 10 & 105 & $1 \cdot 18$ & $1 \cdot 18$ & $1: 0 \cdot 74$ \\
\hline 5 & 10 & 125 & $1 \cdot 26$ & $1 \cdot 11$ & $1: 0 \cdot 88$ \\
\hline - & 10 & 105 & $0 \cdot 36$ & 0.46 & 一 \\
\hline 5 & 10 & 90 & 0.94 & 1.67 & $1: 1 \cdot 4$ \\
\hline $\mathbf{5}$ & 10 & 180 & $1 \cdot 07$ & $1 \cdot 31$ & $1: 1 \cdot 2$ \\
\hline - & 10 & 90 & $0 \cdot 13$ & $0 \cdot 26$ & - \\
\hline $\mathbf{5}$ & $5 \cdot 2$ & 115 & 1.07 & 0.54 & $1: 1 \cdot 3$ \\
\hline- & $5 \cdot 2$ & 275 & 0.49 & $0 \cdot 10$ & 一 \\
\hline
\end{tabular}

Mean $\mathrm{CO}_{2}$ : lactate ratio: $1: 1 \cdot 1(\sigma=0 \cdot 252)$.

sions took place with lactate in the absence of sulphate; in the presence of lactate cell suspensions evolved $1 \mu$ mole $\mathrm{CO}_{2} / \mu$ mole lactate metabolized and $\frac{1}{2} \mu$ mole sulphide was formed (Table 3 ). These observations were consistent with the theoretical equation

$$
2 \mathrm{CH}_{3} \cdot \mathrm{CHOH} \cdot \mathrm{COOH}+\mathrm{Na}_{2} \mathrm{SO}_{4}=2 \mathrm{CH}_{3} \cdot \mathrm{COOH}+2 \mathrm{CO}_{2}+2 \mathrm{H}_{2} \mathrm{O}+\mathrm{Na}_{2} \mathrm{~S} \text {. }
$$

Lactate oxidation by cell suspensions of El Agheila $\mathrm{Z}$ showed the widest variation in $Q_{\mathrm{CO}_{2}}$ encountered during this work; values ranging from 50 to 7 were obtained. Low $Q_{\mathrm{CO}_{2}}$ values, when encountered, were maintained over several subcultures of the strain, and were independent of: $(a)$ the age of the cells harvested; $(b)$ addition of any or all of the components of the lactate medium to the test system; $(c)$ conducting the reaction at $30^{\circ}$ instead of the usual $37^{\circ} ;(d)$ use of $\mathrm{N}_{2}$ specially freed from $\mathrm{O}_{2}$ by passage over a heated copper spiral; $(e)$ use of an unwashed cell suspension; $(f)$ manipulation of the suspension in reducing conditions (excess $\left.\mathrm{Na}_{2} \mathrm{~S}\right) ;(g)$ addition of traces of fumarate $(0.5 \mu$ mole (see Discussion)); $(h)$ increase of the iron content of the medium from which the cells were harvested so that the suspension was black with $\mathrm{FeS}$; $(i)$ decrease of the $\mathrm{Na}_{2} \mathrm{~S}$ in that medium to $0.5 \mu \mathrm{mole} / \mathrm{ml}$.; $(j)$ replacement of sulphate by dithionite, this inducing a negative redox potential in the vessel. Hence this variation seems to be a property of the strain examined; the non-halophilic Hildenborough strain behaved more regularly.

Senez (1951) suggested that pyruvate was an intermediate in the formation 
of acetate from lactate by Desulphovibrio desulphuricans, and this belief was supported (Postgate, 1952 b) by the fact that the rate of pyruvate oxidation by lactate-grown cells was always greater than or equal to the rate of lactate oxidation. Data illustrating this obtained by using methylene blue reduction in Thunberg tubes as a measure of dehydrogenase activity are given in Table 5 . However, unequivocal demonstration of pyruvate as an intermediate was lacking, and attempts were therefore made to demonstrate this by selective inhibition of the hypothetical pyruvate $\rightarrow$ acetate step. Potassium fluoropyruvate $(\mathbf{0} \cdot 25 \mu \mathrm{mole} / \mathrm{mg}$. dry wt. cells) did not affect lactate oxidation at all,

\section{Table 5. Methylene blue reduction by Desulphovibrio desulphuricans strains in presence of certain hydrogen donors}

Washed suspensions of cells harvested from lactate media were incubated in vacuo with methylene blue and hydrogen donor in conventional Thunberg tubes. Times for complete decolorization of methylene blue were recorded.

\begin{tabular}{lcccr} 
Strain & $\ldots$ Hildenborough & El Agheila Z & $\begin{array}{c}\text { New Jersey } \\
\text { SW 8 }\end{array}$ & $\begin{array}{c}\text { New Jersey } \\
\text { SW6 }\end{array}$ \\
Substrate & \multicolumn{4}{c}{ Time for complete decolorization (min.) } \\
Lactate & $\mathbf{3 6}$ & 95 & 62 & 87 \\
Pyruvate & 9 & 44 & 44 & 9 \\
Malate & 65 & 90 & $\infty$ & 121 \\
None & 86 & 116 & $\infty$ & $\infty$ \\
& $(\infty$ signifies $>1000$ min. $)$
\end{tabular}

and caused no keto-acid accumulation; sodium iodoacetate $\left(3 \times 10^{-3} \mathrm{M}\right)$ inhibited the blank metabolism and the lactate oxidation almost completely $\left(Q_{\mathrm{CO}_{2}}\right.$ reduced from 25 to 0.5$) ; 2: 4$-dinitrophenylhydrazine decreased the rate of lactate oxidation $\left(Q_{\mathrm{CO}_{2}}\right.$ of 25) to a $Q_{\mathrm{Co}_{2}}$ of 13 , but no accumulation of acid phenylhydrazone was observed. Sodium arsenite $(0.01 \mathrm{~m}$ to $0.0025 \mathrm{M})$, however, decreased the $Q_{\mathrm{CO}_{2}}$ with lactate by about $50 \%$ and, provided the uninhibited $Q_{\mathrm{CO}_{2}}$ value was greater than $c$. 20, caused significant and reproducible accumulation of pyruvate. No keto-acid was detected in the absence of lactate. Since pyruvate metabolism still took place in the presence of arsenite, quantitative conversion of lactate to pyruvate was not to be expected. However, up to $12 \%$ of the lactate utilized could be accounted for as pyruvate (Table 6). Since the demonstration of pyruvate formation from lactate was of some general importance, it was desirable to repeat these experiments with a second strain of these bacteria. Table 6 includes some experiments showing pyruvate accumulation by arsenite-inhibited cells of the Hildenborough strain harvested from a lactate medium.

Pyruvate formation from malate was not successfully demonstrated because arsenite had a stronger inhibitory effect on the initial attack on malate than on pyruvate oxidation: even at $0.0001 \mathrm{M}$ it decreased the $Q_{\mathrm{Co}_{2}}$ by $c .50 \%$; no keto-acid accumulated. 


\section{Pyruvate oxidation}

The metabolism of pyruvate was already known to be complex owing to the apparent existence of two pathways of 'sulphate-free' metabolism as well as the oxidation in the presence of sulphate. It is hoped to report a detailed study of these reactions at a later date; in the present work the study of pyruvate metabolism was restricted to establishing the stoichiometry of its reaction with sulphate. Cultures of strain El Agheila $\mathrm{Z}$ grew to higher cell densities with

\section{Table 6. Formation of pyruvate from lactate by arsenite-inhibited Desulphovibrio desulphuricans strains}

Cell suspensions were shaken in Warburg manometers $\left(37^{\circ}, \mathrm{N}_{2}\right)$ with $\mathrm{Na}$ lactate $(5 \mu$ mole) $\mathrm{Na}_{2} \mathrm{SO}_{4}(20 \mu$ mole $) \mathrm{Na}$ arsenite, $0.01 \mathrm{~m}, \mathrm{pH} \mathrm{6.9}$, for various times and the supernatant analysed for pyruvate and residual lactate.

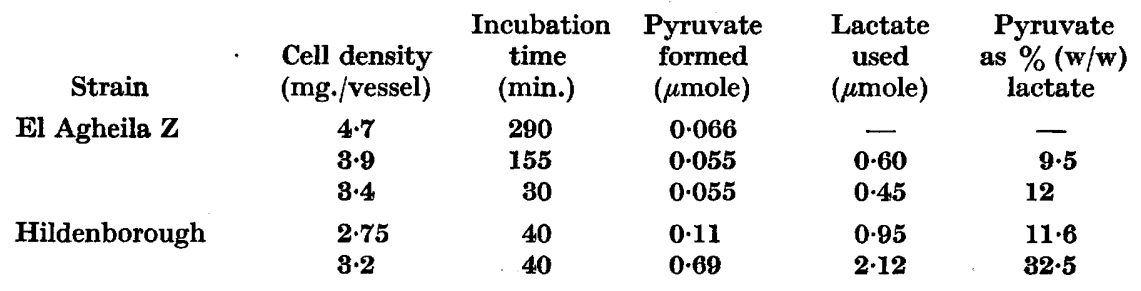

pyruvate + sulphate than with equimolar lactate or malate (see Senez, 1951), and analysis of cultures grown in these conditions gave a final yield of $1 \mu$ mole acetate $/ \mu$ mole of pyruvate utilized (Table 1 ). Cells harvested from lactate medium oxidized pyruvate without a lag with a $Q_{\mathrm{co}_{2}}$ of $c .45$ (range: 80 to 40); the quotient was never less than that with lactate and often exceeded it; $1 \mu$ mole $\mathrm{CO}_{2}$ was evolved/ $\mu$ mole pyruvate oxidized and $\frac{1}{4} \mu$ mole $S^{\prime \prime}$ was formed (Table 3). These observations are consistent with the equation:

$$
4 \mathrm{CH}_{3} \cdot \mathrm{CO} \cdot \mathrm{COOH}+\mathrm{Na}_{2} \mathrm{SO}_{4}=4 \mathrm{CH}_{3} \cdot \mathrm{COOH}+4 \mathrm{CO}_{2}+\mathrm{Na}_{2} \mathrm{~S} \text {. }
$$

\section{Effect of carbon compounds on sulphate reduction in hydrogen}

Senez $(1954, b)$ reported that the rate at which heterotrophically-grown cells of Desulphovibrio desulphuricans strain Canet 41 reduced sulphate in hydrogen was enhanced by pyruvate or lactate, in spite of the fact that the carbon compounds were oxidized simultaneously. Similar effects were demonstrated with malate-grown El Agheila $Z$, provided the $-Q_{\mathrm{H}_{2}}^{\mathrm{SO}_{2} \text { " was determined with }}$ cells that had been pre-incubated for some time in $\mathrm{N}_{2}$ with excess $\mathrm{Na}_{2} \mathrm{SO}_{4}$ to bring stored carbon compounds to a low concentration. Marked stimulation of sulphate reduction occurred regularly if small amounts of fumarate or malate were present, but succinate, lactate and pyruvate did not usually have an effect (Table 7 ).

Fisher, Krasna \& Rittenberg (1954) showed that a lag in the hydrogenase activity of Proteus vulgaris was reduced by metabolic substrates such as glucose or fumarate, as well as by dithionite, and attributed this to removal 
of dissolved oxygen from the system, thus converting hydrogenase from an inactive oxygenated form to an active de-oxygenated form. This explanation probably accounts for the comparable phenomena observed with Desulphovibrio desulphuricans, since stimulation of the $-\boldsymbol{Q}_{\mathbf{H}_{2}}$ by organic compounds was not observed if dithionite replaced sulphate as hydrogen acceptor (Table 7).

Table 7. Influence of certain carbon compounds on the rate of substrate reduction with hydrogen by Desulphovibrio desulphuricans strain El Agheila Z

(A) With sulphate: cell suspensions were incubated (1 to $2 \mathrm{hr}$.) in $\mathrm{N}_{2}$ at $37^{\circ}$ with $\mathrm{Na}_{2} \mathrm{SO}_{4}$ $\left(2 \times 10^{-3} \mathrm{M}\right)$, washed by centrifugation and the $-Q_{\mathrm{H}_{2}}^{\mathrm{SO}_{4}}$ determined manometrically at $37^{\circ}$ and pH 6.1 with $0.5 \mu$ mole organic supplements. $\mathrm{NaOH}(0.25 \mathrm{ml} .20 \% \mathrm{w} / \mathrm{v})$ replaced $\mathrm{CdCl}_{2}$ in the centre well to absorb $\mathrm{CO}_{2}$ formed from the carbon sources. - $\mathbf{Q}_{\mathrm{H}}^{\mathrm{SO}} \mathrm{O}^{\prime \prime}$ values from four experiments are quoted.

$\begin{array}{ccccc}\begin{array}{c}\text { Experiment } \ldots \\ \text { Supplement }\end{array} & 1 & 2 & 3 & 4 \\ - & 16 & 17 & 12 & 26 \\ \text { Malate } & \mathbf{2 4} & 33 & 17 & 35 \\ \text { Fumarate } & 26 & 46 & 20 & 30 \\ \text { Succinate } & 17 & 17 & 11 & -12 \\ \text { Lactate } & - & 22 & 12 & 27 \\ \text { Pyruvate } & - & 17 & 10 & 42\end{array}$

(B) With dithionite: cell suspensions were treated as above; sodium dithionate was added as $c .1 \mathrm{mg}$. solid. $-Q_{\mathrm{H}_{2}}$ values from two experiments are quoted.

$\begin{array}{lrrr}\text { Experiment } \quad \cdots & \cdots & 1 & 2 \\ \text { Substrates } & & 46 & 43 \\ \text { Sulphate } & & \mathbf{7 7} & \mathbf{7 2} \\ \text { Sulphate and fumarate } & & 154 & 111 \\ \text { Dithionite } & & 155 & 109 \\ \text { Dithionite and fumarate } & & \end{array}$

\section{DISCUSSION}

A scheme for malate metabolism in Desulphovibrio desulphuricans

Since fumarate and malate are formed by CTAB-treated cells when either compound is added initially, the primary step in malate metabolism is clearly a fumarase type of reaction leading to an equilibrium mixture of malate and fumarate. Subsequent to this, several steps take place, in the absence of sulphate, which, in undamaged cells, lead to the formation of succinate and acetate. The stoichiometry of this reaction corresponded most closely to 3 malate $\rightarrow 2$ succinate +1 acetate $+2 \mathrm{CO}_{2}$ (Table 2 ), from which it is necessary to postulate that two molecules of fumarate are reduced during the oxidation of one molecule of malate to yield the two molecules of succinate. Stoichiometrically, then, one can write the two equations:

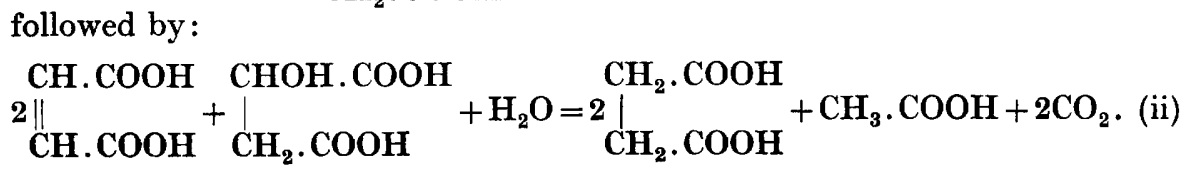

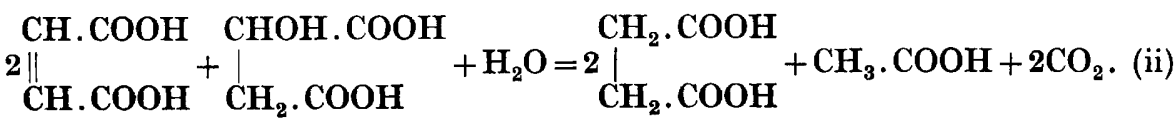$$
\underset{\mathrm{CH}_{2} \cdot \mathrm{COOH}}{\mathrm{CHOH} \cdot \mathrm{COOH}} \underset{\mathrm{CH} \cdot \mathrm{COOH}}{\mathrm{CH}}+\mathrm{CH}_{2} \mathrm{O},
$$ 
Acetate, succinate and $\mathrm{CO}_{2}$ could in theory be formed by a second type of breakdown in which ethanol would be expected as an additional end product:

$$
\begin{aligned}
& \mathrm{CHOH} . \mathrm{COOH} \mathrm{CH}_{2} \text {. } \mathrm{COOH} \\
& \left.3\right|_{\mathrm{CH}_{2}} \cdot \mathrm{COOH}=\mathrm{CH}_{2} \cdot \mathrm{COOH}+2 \mathrm{CH}_{3} \cdot \mathrm{COOH}+\mathrm{CH}_{3} \mathrm{CH}_{2} \mathrm{OH}+2 \mathrm{CO}_{2} \text {. }
\end{aligned}
$$

This reaction requires, however, not only that ethanol be formed but that 3 malate yield 2 acetate +1 succinate +1 ethanol $+2 \mathrm{CO}_{2}$. This bears no relation to the analytical figures obtained, though traces of material that may have been ethanol were in fact found in the products of malate breakdown without sulphate. Thus, if this reaction occurs at all, it is unimportant, and equations (i) and (ii) probably give the most satisfactory account of malate dismutation.

The reduction of the two fumarate molecules to succinate is coupled, in the absence of sulphate, with oxidation of malate to acetate, and the formation of lactate by CTAB-treated cells indicates that lactate is involved in this step. The formation of pyruvate from lactate by arsenite-inhibited cells provides direct evidence supporting the view that pyruvate is an intermediate in lactate breakdown, and, though pyruvate formation from malate was not observed, it is reasonable to suppose that pyruvate formation in fact took place since lactate formation was demonstrated. Thus the oxidation of malate which parallels reduction of fumarate to succinate probably follows the courses:

$$
\underset{\mathrm{CH}_{2} \cdot \mathrm{COOH}}{\mathrm{CHOH} \cdot \mathrm{COOH}}=\underset{\mathrm{CH}_{3}}{\mathrm{CHOH} \cdot \mathrm{COOH}}+\mathrm{CO}_{2} \text {, }
$$

then

then

$$
\mathrm{CH}_{3} \cdot \mathrm{CHOH} \cdot \mathrm{COOH}+\underset{\mathrm{CH} \cdot \mathrm{COOH}}{\mathrm{CH}}=\underset{\mathrm{CH}_{2} \cdot \mathrm{COOH}}{\mathrm{CH}_{2} \cdot \mathrm{COOH}}+\mathrm{CH}_{3} \cdot \mathrm{CO} \cdot \mathrm{COOH},
$$

$$
\mathrm{CH}_{3} \cdot \mathrm{CO} \cdot \mathrm{COOH}+\underset{\mathrm{CH} \cdot \mathrm{COOH}}{\mathrm{CH}} \cdot \mathrm{COOH}+\mathrm{H}_{2} \mathrm{O}=\underset{\mathrm{CH}_{2}}{\stackrel{\mathrm{CH}_{2}}{d} \cdot \mathrm{COOH}}+\mathrm{CH}_{3} \cdot \mathrm{COOH}+\mathrm{CO}_{2} .
$$

Oxido-reductions of the kind represented in (v) and (vi) are well known in other bacteria (see Stephenson, 1949). Equations (i), (ii), (iv), (v) and (vi) can be combined to form the scheme of malate metabolism shown in Fig. 3.

Lactate and pyruvate have been written as successive stages in the oxidative side of the scheme shown in Fig. 3. There is, however, no evidence from this work against the possibility that pyruvate is the initial product and that lactate is in equilibrium with it; this is thought to occur in the malic decarboxylase system of Lactobacillus arabinosus (Korkes, Campillo \& Ochoa, 1950).

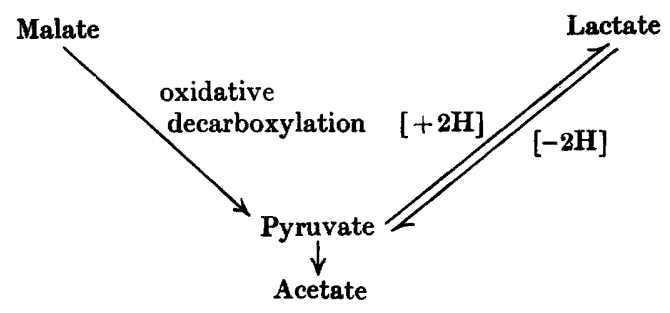


So far the discussion has been restricted to malate breakdown without sulphate, but there is strong evidence that similar reactions take place when sulphate is present. The evidence may be summarized: (i) succinate accumulates transiently during oxidation of malate in the Warburg manometer; (ii) cultures of bacteria which have not oxidized all the available malate contain an excess of acetate above the theoretical value for straightforward oxidation by sulphate; hence acetate formation uncoupled with sulphate reduction is occurring; (iii) succinate, fumarate and lactate were demonstrated chromatographically in such cultures-though no data concerning amounts present were available.

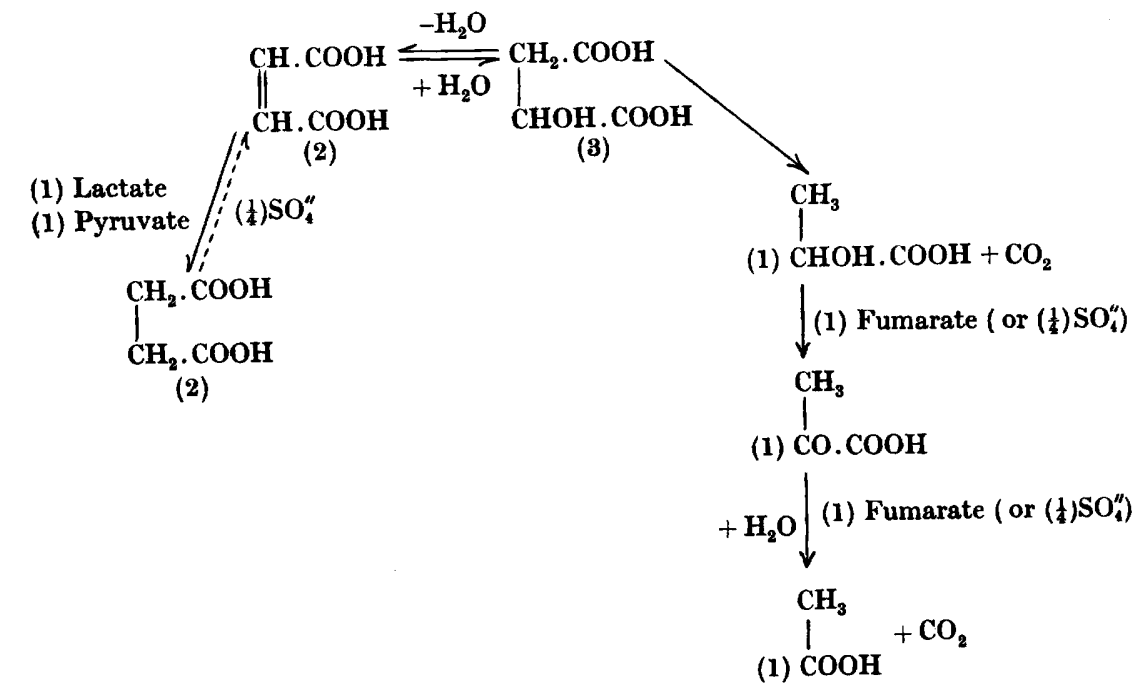

Fig. 3. Scheme for malate metabolism in Desulphovibrio desulphuricans. The numbers preceding the names or structures of compounds indicate the number of molecules participating in each metabolic step.

This view leads to the rather surprising conclusion that there is only one reaction in the metabolism of malate for which sulphate is essential, that is, the oxidation of succinate to fumarate. Obviously, sulphate reduction can be linked to lactate oxidation and pyruvate oxidation; indeed, it is essential for the former if malate or fumarate are absent, but fumarate can act as an alternative hydrogen acceptor to sulphate for all reactions except its formation from succinate, and in fact does so even when sulphate is present.

\section{The role of fumarate as a hydrogen acceptor}

Sisler \& ZoBell (1951) postulated a reductive fission of fumarate to yield acetate; the present work indicates that the reduction proceeds only as far as succinate. The reaction is not necessarily associated with malate metabolism since $(a)$ Sisler \& ZoBell first observed it in autotrophically grown cells, $(b)$ in the present work it was observed in lactate-grown cells of Sisler \& ZoBell's strain, (c) both lactate- and malate-grown cells of El Agheila $\mathrm{Z}$ conducted the reaction. It seems probable, then, that fumarate 
reduction in hydrogen is a property common to all hydrogenase-containing strains of Desulphovibrio desulphuricans and that the failure to demonstrate it with strains Hildenborough, New Jersey SW 8 and Canet 41 was due to the reaction proceeding at a rate lower than that of the 'blank' hydrogen absorption; the strain California 43:63 may be exceptional only in that it conducts the reaction rapidly.

The argument outlined in the preceding section establishes that fumarate can also act as hydrogen acceptor for the oxidation of lactate and of pyruvate. The only reaction in the sequence (Fig. 3) proposed for which sulphate is essential is the oxidation of succinate. If succinate oxidation proceeds by way of fumarate, as the sequence above assumed, one can envisage a scheme in which the oxidation of succinate would be linked to sulphate reduction, and the reduction of fumarate would be linked with the oxidation of hydrogen, lactate or pyruvate. A fumarate-succinate cycle would thus be part of the electron-transfer system between the oxidation of hydrogen donors and the reduction of sulphate:
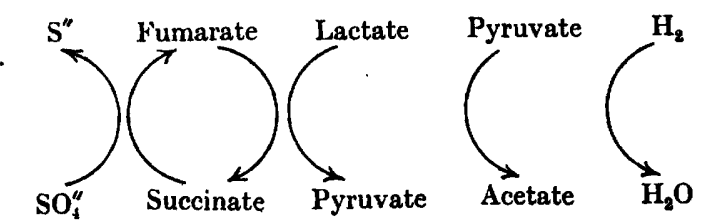

Such a view would be consistent with the report of Senez $(1954 a)$ of the presence of malic, fumaric and succinic dehydrogenase systems in lactategrown El Agheila Z. This hypothesis is consistent with the facts reported here, but before it can be proved or disproved it requires a more detailed examination of the precise factors which link carbon oxidation to sulphate reduction. It is, however, pertinent to point out that the analogous system in all other organisms, the succinoxidase system, is cytochrome linked, and Postgate $(1954, a, b)$ showed that the cytochrome of Desulphovibrio desulphuricans was directly involved in sulphate reduction.

We are indebted to our colleagues in the Microbiology Group, C.R.L., for helpful discussions during this work, as well as for valuable criticisms of the manuscript. The paper is published by permission of the Director, Chemical Research Laboratory.

\section{REFERENCES}

Adams, M. E., Butlin, K. R., Hollands, S. J. \& Postgate, J. R. (1951). Role of hydrogenase in the autotrophy of Desulphovibrio. Research, 4, 245.

BaARS, J. K. (1930). Over Sulfaatreductie door Bacteriën. Dissertation, W.D. Meinema, Delft.

Barker, S. B. \& Summerson, W. H. (1941). The colorimetric determination of lactic acid in biological material. J. biol. Chem. 138, 535.

BeiJerinck, M. W. (1895). Utber Spirillum desulfuricans als Ursache von Sulfatreduktion. Zbl. Bakt. (2. Abt.), 1, 1, 49, 104.

Buthr, K. R. \& Adams, M. E. (1947). Autotrophic growth of sulphate-reducing bacteria. Nature, Lond. 160, 154. 


\section{Malate metabolism in D. desulphuricans}

Butuin, K. R., Adams, M. E. \& Thomas, M. (1949). The isolation and cultivation of sulphate-reducing bacteria. J. gen. Microbiol. 3, 46.

Chemistry Research 1952 (1953). Rep. Chem. Res. Bd., Lond., H.M.S.O.

Delden, A. van (1903). Beitrag zur Kenntnis der Sulfatreduktion durch Bakterien. Zbl. Bakt. (2. Abt.), 11, 81, 113.

Fisher, H. F., Krasna, A. I. \& Rittenberg, D. (1954). The interaction of hydrogenase with oxygen. J. biol. Chem. 209, 569 .

Friedemann, T. E. (1938). The identification and quantitative determination of volatile alcohols and acids. J. biol. Chem. 123, 161.

Friedemann, T. E. \& Haugen, G. E. (1943). Pyruvic acid. II. The determination of keto-acids in blood and urine. J. biol. Chem. 147, 415.

Grossman, J. P. \& Postgate, J. R. (1953). The cultivation of sulphate-reducing bacteria. Nature, Lond. 171, 600.

Korkes, S., del Campillo, A. \& Ochoa, S. (1950). Biosynthesis of dicarboxylic acids by carbon dioxide fixation. IV. J. biol. Chem. 187, 891 .

Millet, J. (1954). Dégradation anaérobie du pyruvate par un extrait enzymatique de Desulphovibrio desulphuricans. C.R. Acad. Sci., Paris, 238, 408.

Neish, A. C. (1950). Analytical Methods for Bacterial Fermentation. Nat. Res. Coun. of Canada Rep. no. 46-8-3. Saskatoon.

Nossal, P. M. (1951). The decarboxylation of malic acid by Lactobacillus arabinosus. Biochem. J. 49, 407.

Postgate, J. R. (1951). The reduction of sulphur compounds by Desulphovibrio desulphuricans. J. gen. Microbiol. 5, 725.

Postgate, J. R. (1952a). Growth of sulphate-reducing bacteria in sulphate-free media. Research, $5,189$.

Postgate, J. R. $(\mathbf{1 9 5 2} b)$. The utilisation of pyruvate by sulphate reducers. Abstr. 2nd Int. Congr. Biochem. Paris, p. 92.

Postgate, J. R. (1953). On the nutrition of Desulphovibrio desulphuricans; a correction. J. gen. Microbiol. 9, 440.

Postgate, J. R. (1954a). Presence of cytochrome in an obligate anaerobe. Biochem. J. 56, xi.

Postgate, J. R. (1954b). Dependence of sulphate reduction and oxygen utilization on a cytochrome in Desulphovibrio. Biochem. J. 58, ix.

Sadana, J. C. (1954). Pyruvate oxidation in Desulphovibrio desulphuricans. J. Bact. $67,547$.

SenEz, J. C. (1951). Étude comparative de la croissance de Sporovibrio desulphuricans sur pyruvate et sur lactate de soude. Ann. Inst. Pasteur, 80, 395.

SenEz, J. C. (1953). Sur l'activité et la croissance des bactéries anaérobies sulfatoréductrices en cultures semi-autotrophes. Ann. Inst. Pasteur, 84, 595.

Senez, J. C. (1954 $a$ ). Fermentation de l'acide pyruvique et des acides dicarboxyliques par les bactéries anaérobies sulfato-réductrices. Bull. Soc. Chim. biol., Paris, 36, 541 .

SENEz, J. C. (1954b). Concurrence of autotrophic and heterotrophic metabolism in growing and in resting cells of sulphate-reducing bacteria. J. gen. Microbiol. 11, vi.

Senez, J. C. \& Leroux-Gilleron, J. (1954). Note préliminaire sur la dégradation anaérobie de la cystéine et de la cystine par les bactéries sulfato-réductrices. Bull. Soc. Chim. biol., Paris, 36, 553.

Sisler, F. D. \& ZoBell, C. E. (1951). Hydrogen utilization by some marine sulphate-reducing bacteria. J. Bact. 62, 117 .

Stephenson, M. (1949). Bacterial Metabolism, 3rd ed., p. 46. London: Longmans, Green and Co. 